\title{
ESTIMATING THE COST \\ OF CAPITAL FOR WIND \\ ENERGY INVESTMENTS \\ IN TURKEY
}

SIMONE TAGLIAPIETRA, GEORG ZACHMANN AND GUSTAV FREDRIKSSON

Wind power represents a key component of Turkey's energy strategy. Increased investment will be required to meet Turkey's wind power target and, as such, there is a need to understand the viability of wind power projects there. The cost of capital is a crucial element in wind power investment decisions owing to the high capital intensity of wind power plants. A reduction in the cost of capital through support policies can lower overall project costs and increase investment. We estimate the cost of capital for wind power projects in Turkey using data on 138 installations that participated in the Turkish feed-in tariff scheme in 2017. Our estimates indicate an upper bound of $12 \%$ for the cost of capital. This suggests the cost of capital for wind power projects in Turkey is not higher than in south-eastern European Union countries. However, because of adverse macroeconomic conditions, the cost of Turkey's main renewable support scheme increased by $46 \%$ between 2016 and 2017 in Turkish lira terms. We argue that continued commitment to the current support schemes by the Turkish authorities is crucial for the development of the Turkish wind power sector.

Simone Tagliapietra is research fellow at Bruegel. Georg Zachmann is a senior fellow at Bruegel. Gustav Fredriksson is a PhD candidate in Environmental and Energy Economics at ETH Zürich. 


\section{Introduction}

Since 2002, Turkey's electricity consumption has increased at a remarkable rate of $5.1 \%$ a year, reaching a level of 292.6 TWh in 2017 (EPDK, 2018). The strong demand has mainly been met by natural gas $[36.8 \%$ of the generation mix in 2017], coal and lignite [33.0\%], hydro power [19.8\%], wind [6.1\%], geothermal [2.0\%] and solar $(1.0 \%)^{1}$. The growth in electricity consumption is expected to continue and to reach $385 \mathrm{TWh}$ in 2023 (Republic of Turkey Ministry of Energy and Natural Resources, 2019a).

Turkey has an installed electricity generation capacity of $84.7 \mathrm{GW}$, made up of $26.4 \mathrm{GW}$ of natural gas, $27.3 \mathrm{GW}$ of hydro power, 19.2 GW of coal and lignite, and 6.5 GW of wind (EPDK, 2018). In order to cope with the growing demand, the country has adopted a 2023 strategy including targets to reach an installed electricity generation capacity of $20 \mathrm{GW}$ for wind, $5 \mathrm{GW}$ of solar and $1 \mathrm{GW}$ of geothermal by 2023. The strategy consists of four key aims: i) strengthening security of supply to meet demand and reduce import dependence; ii] addressing environmental concerns in the energy chain; iii) increasing energy efficiency; and iv) promoting R\&D in energy technologies (Republic of Turkey Ministry of Foreign Affairs, n.d.).

As suggested by the strategy's first aim, high import dependence is a major issue for the Turkish energy sector. Turkey can only meet around a quarter of its energy demand from domestic resources. In the electricity sector, Turkey uses imported coal and natural gas to meet its rapidly increasing demand. Reducing energy imports by prioritizing domestic energy resources such as coal and renewables has been a long-lasting strategy in the country. This is not only due to energy security concerns, but also because of macroeconomic considerations. In effect, energy imports represent a major burden for the country's current account balance. In 2017 the Turkish import bill stood at 234 billion US dollars (Turkish Statistical Institute, 2018), of which 37.2 billion US dollars were spent on energy imports (Sengul, 2018). In the same year, the Turkish trade deficit was 77 billion US dollars (Turkish Statistical Institute, 2018). Reducing the energy import dependence is also a fundamental prerequisite for Turkey's industrial and export competitiveness. The Turkish economy is centred around energy-intensive industries such as automotive, machineries, industrial equipment, and iron and steel, for which the provision of secure and affordable energy is important.

\footnotetext{
${ }^{1}$ Other minor sources include biomass $[0.7 \%$ and diesel and fuel oil $[0.7 \%$. We count licensed and unlicensed power plants as reported by EPDK [2018).
} 
In this context, to increase the attractiveness of investment in renewable energy projects, the Turkish government has put in place two renewable support schemes. The first is the YEKDEM scheme, which guarantees feed-intariffs for ten years to operators of renewable energy plants. YEKDEM was introduced in 2011 and is set to remain in place until the end of $2020^{2}$. The second means of support is the YEKA programme, under which the government offers a 'renewable energy resource zone' and electrical connection capacity to investors that commit to invest in local research and development, purchase domestically-produced equipment and employ a large share of domestic workers. These projects are reverse-auctioned from a maximum electricity purchase price, which is guaranteed for a specified period. The YEKA programme was introduced in 2016. In 2017 two tenders, one for wind ( $1 \mathrm{GW}$ installed capacity) and one for solar $[1 \mathrm{GW}$ ), were successfully auctioned. Six tenders for wind and solar power projects were planned to be auctioned in 2018 (Invest in Turkey, 2018).

This paper presents an estimate of the cost of capital for wind power investments in Turkey under the YEKDEM feed-in tariff scheme. As wind power is highly capital-intensive compared to conventional energy, the cost of capital represents a crucial element in wind power investment decisions. In short, a high cost of capital substantially increases the cost of investment in wind power plants. Given the primary role of wind power in Turkey's 2023 energy strategy, it is important to have a better understanding of this factor in the Turkish context, especially since it has received limited attention from the literature. Moreover, the 2023 strategy's emphasis on wind power owes largely to Turkey's strong wind power potential. The Turkish government estimates that $48 \mathrm{GW}$ could be produced by wind farms that would occupy just $1.3 \%$ of the total surface area of Turkey (Republic of Turkey Ministry of Energy and Natural Resources, 2019b].

Assessing the cost of capital is also valuable in view of the current investment climate. High inflation ${ }^{3}$ and devaluation of the Turkish lira against the US dollar ${ }^{4}$ contributed to foreign direct investment in Turkey falling from 19 billion US dollars in 2015 to 11 billion US dollars in 2017 (OECD, 2019a). As feed-in tariffs under the YEKDEM scheme are fixed in US dollars, the inflation and devaluation are partially offset for investors. The costs of the feedin tariffs are instead borne by Turkish electricity consumers who are invoiced in Turkish lira and faced a 13.4\%

\footnotetext{
2 Turkey's Minister of Energy confirmed that YEKDEM will not continue after 2020 (Enerji I0, 2017). Projects that were approved for YEKDEM before 2020 will continue to receive any outstanding support after 2020 though. Thus, a project joining YEKDEM in, for instance, 2019 will have access to the feed-in-tariffs until 2029.

$320 \%$ increase between 2015 and 2017 (calculated using data from IMF, 2018).

$434 \%$ change between 2015 and 2017 (calculated using data from OECD, 2019b).
} 
increase in the wholesale electricity price between 2016 and 2017 (EPDK, 2018). We calculate the total cost of the YEKDEM scheme and discuss possible policy responses.

There are several reasons to concentrate on the YEKDEM scheme in this paper. Firstly, YEKDEM covered 141 wind power plants in 2017, giving us the necessary data to pursue a meaningful quantitative analysis. In contrast, because it was recently introduced, the YEKA programme covered only one wind power project in 2017. Second, the YEKA programme aims to promote large-scale projects that create local spillover effects in terms of research and workforce specialization. This is strategically important for the long-run development of renewable energy production in Turkey. However, to reach the 2023 targets, it is crucial to continue attracting and retaining investments in small- and medium-scale renewable energy projects. Hence, this paper looks specifically into the incentives to foster the uptake of small- and medium-sized power projects. Nevertheless, we outline in the conclusion and policy recommendations that our findings have important implications not only for the YEKDEM support scheme but also for the YEKA programme.

This paper is structured as follows. Section 2 reviews the literature on the cost of capital in the context of wind power investments. Section 3 illustrates the methodology and data used to estimate the cost of capital for wind power projects in Turkey. Section 4 presents the results of this estimation while Section 5 analyzes the total cost of the YEKDEM scheme. Section 6 concludes with policy recommendations.

\section{Literature review}

The importance of a low cost of capital for wind power investment is well recognized in the literature. Hirth and Steckel (2016) showed that wind power can be cheaper than fossil-fuelled plants if the weighted average cost of capital (WACC) is low. However, the authors illustrated that this relationship is eventually reversed as the WACC increases, even if carbon emissions are taxed heavily. Looking at countries of different income levels, Waissbein et al (2013) argued that financing costs for renewable energy projects can be especially high in developing countries, which can limit their competitiveness there. The close relationship between the cost of capital and the level of renewable energy investment has generated interest in the determinants of the cost of capital. Steckel and Jakob (2018), for instance, argued that a more stable policy environment, including better 
designed regulation and increased transparency, as well as measures aimed at de-risking private investments, can help reduce the cost of capital for renewable energy investment.

Several studies have sought to quantify the cost of capital in Europe. Noothout et al (2016) and Tesniere et al (2017) estimated the WACC for renewable energy projects and validated their estimates in interviews with experts. They found that the WACC can differ substantially between countries. In the EU, Noothout et al (2016), as part of the DiaCore project, found a range from 3.5\% in Germany to $12 \%$ in Greece for onshore wind power installations. Tesniere et al (2017) updated the analysis for onshore wind in south-eastern EU member states for 2015 in an Ecofys study, and concluded that the WACC varied between 5\% (Slovakia) and 13.7\% (Greece). Temperton [2016] showed that an equalization of the cost of capital throughout the EU could reduce the cost of reaching the 2030 renewable energy targets and help spread the benefits of renewable energy investment across member states.

Turning to the situation in Turkey, Simsek and Simsek (2013) evaluated the YEKDEM scheme and highlighted the need for transparent and predictable support mechanisms for renewable energy investment. Looking into the welfare effects of renewable energy, Bulut and Muratoglu [2018] found no evidence for causality between renewable energy consumption and GDP in Turkey. However, based on an analysis using an Analytic Hierarchy Process model, Pasaoglu et al (2018) recommended increasing the share of renewable power in Turkey.

Various studies have emphasized the importance of wind power for decarbonizing Turkish energy production. Azman et al (2015] highlighted that its geographical location offers Turkey a particular advantage in wind power production. Based on an integrated life cycle sustainability assessment, Atilgan and Azapagic [2016) found that hydro power, followed by geothermal and wind power, are the most sustainable energy sources in Turkey. Similarly, the International Institute for Sustainable Development [2015] argued that wind power is cheaper than solar power and coal in Turkey, once costs related to subsidies, health and the environment are considered.

Few studies have calculated the cost of capital for wind power projects in Turkey. A study by Ertürk (2012) estimated a weighted average of the cost of debt and equity for onshore wind power projects in Turkey, and found a WACC of $9.4 \%$. This approach differs from the one employed in this paper, however, as we deduced a reasonable range of the cost of capital from the internal rate of return. This is discussed in greater detail in the following section. 


\section{Methodology and data}

The cost of capital for investment projects can be calculated using various approaches. For renewable energy projects, it is common to estimate the WACC. The WACC is calculated in equation (3) as the weighted sum of the estimated cost of debt and the estimated cost of equity, where $D$ and $E$ are the market values of a company's debt and equity respectively, and $\tau$ is the tax rate.

$$
\begin{aligned}
& \text { Cost of debt }=r_{f}+\text { Risk premium } \\
& \text { Cost of equity }=r_{f}+\beta\left(r_{m}-r_{f}\right) \\
& \text { WACC }=\frac{D}{D+E} * \text { Cost of debt } *(1-\tau)+\frac{E}{D+E} * \text { Cost of equity }
\end{aligned}
$$

Equation (1) shows that the cost of debt is usually estimated as the risk-free rate of return $\left[r_{f}\right]$ plus a companyspecific risk premium. As depicted in equation [2], the cost of equity typically ${ }^{5}$ refers to the risk-free rate plus the risk premium of the market [as $r_{m}$ is the market return], weighted by $\beta$, which measures the riskiness of a given company relative to the market as a whole.

It is inherently difficult to estimate the parameters in equations (1)-(3). Measuring $\beta$ requires information on the riskiness of wind power projects in Turkey relative to the market as a whole, which is not readily available. Ertürk [2012] proxied $\beta$ for Turkish wind power projects with US data, though it is unclear whether the relative risk profile of wind power projects is the same in the US as in Turkey. Estimating the risk premium for renewable energy producers is similarly challenging because of the lack of available data on Turkish renewable energy investments. Furthermore, calculating the WACC using equation (3) requires knowledge of the market value of debt and equity of wind producers in Turkey. This information is often confidential and is hard to obtain.

Because of the difficulty of reliably estimating the parameters in equations (1)-[3], many studies validate their estimates in interviews with experts. This implies that the final WACC estimates rely on self-reported investment behaviour, making them subjective to a degree.

In view of those shortcomings, we employed a different approach. We calculated the internal rate of return (IRR) of wind projects in Turkey, and used the IRR as an upper bound of the cost of capital. The IRR is the discount rate that sets the net present value (NPV) of a project's cash flows (CF) equal to zero, as follows:

\footnotetext{
${ }^{5}$ Equation [2] is known as the Capital Asset Pricing Model.
} 


$$
N P V=0=\sum_{t} \frac{C F_{t}}{(1+I R R)^{t}}
$$

The IRR is closely related to the cost of capital. If the cost of capital exceeds the IRR, a project has a negative NPV and hence a negative rate of return for investors. Conversely, a cost of capital below the IRR implies that the project yields an excess return, which is what investors would normally require to finance a project. This relationship is summarized in equation [5]:

$$
I R R-\text { Cost of capital }=\text { Excess return }
$$

We can deduce a range of plausible cost of capitals from the IRR by assuming that the average wind power project in Turkey generates a positive return. Therefore, the IRR gives the upper bound of the cost of capital, since a cost of capital exceeding the IRR implies a negative return.

Calculating the IRR requires information on yearly cash flows and the project lifetime $[n]$. We calculate the net cash flow in year $t$ by subtracting costs from revenues in that year. Equation [6] decomposes the different elements of the cash flows and describes how we calculate the IRR:

$$
N P V=0=-I_{0}+\sum_{t=1}^{n} \frac{R_{t}-O \& M_{t}-T_{t}}{(1+I R R)^{t}}+\frac{S V_{n+1}}{(1+I R R)^{n+1}}
$$

Costs include one-time capital costs for setting up the project $\left[I_{0}\right]$, yearly recurring operation and maintenance costs $\left[O \& M_{t}\right]$ and taxes $\left[T_{t}\right]$. Note that we abstract from overhead costs and assume that there are no taxes and 0\&M costs incurred in the first year (period 0). Furthermore, for simplicity, we do not distinguish between equity and debt financing and therefore exclude interest payments to external creditors ${ }^{6}$.

Revenues are composed of yearly revenues from electricity sales $\left[R_{t}\right]$ and a one-time pay-out at the end of the project's lifetime that reflects the value of the installation after the project has ended (we call this the salvage value, $S V_{n+1}$ ]. Note that there is no revenue from electricity sales in period 0 .

Our analysis makes use of a dataset from the Energy Market Regulatory Authority of Turkey (EPDK, 2019) which contains plant-level data for all participants in the Turkish YEKDEM feed-in tariff scheme. The data consist of plantspecific feed-in tariffs (in US dollars), yearly production volumes (in MWh), production capacities (in MW) and an

\footnotetext{
${ }^{6}$ We are only interested in the overall cost of capital and not its composition of equity and debt. To calculate the return on a project, we therefore implicitly assume that the whole project is financed by equity.
} 
ex ante estimate of what the power plant might generate in one year (in MWh]? Figure 1 shows the scope of the Turkish YEKDEM scheme in 2017. Next to many hydro power, bioenergy and geothermal plants ${ }^{8}$, YEKDEM covered 138 wind power installations with positive output in $2017^{9}$ that had an installed capacity of almost $5.2 \mathrm{GW}$ and produced 14.8 TWh of electricity in 2017.

Figure 1. Technologies licenced under the YEKDEM scheme in 2017

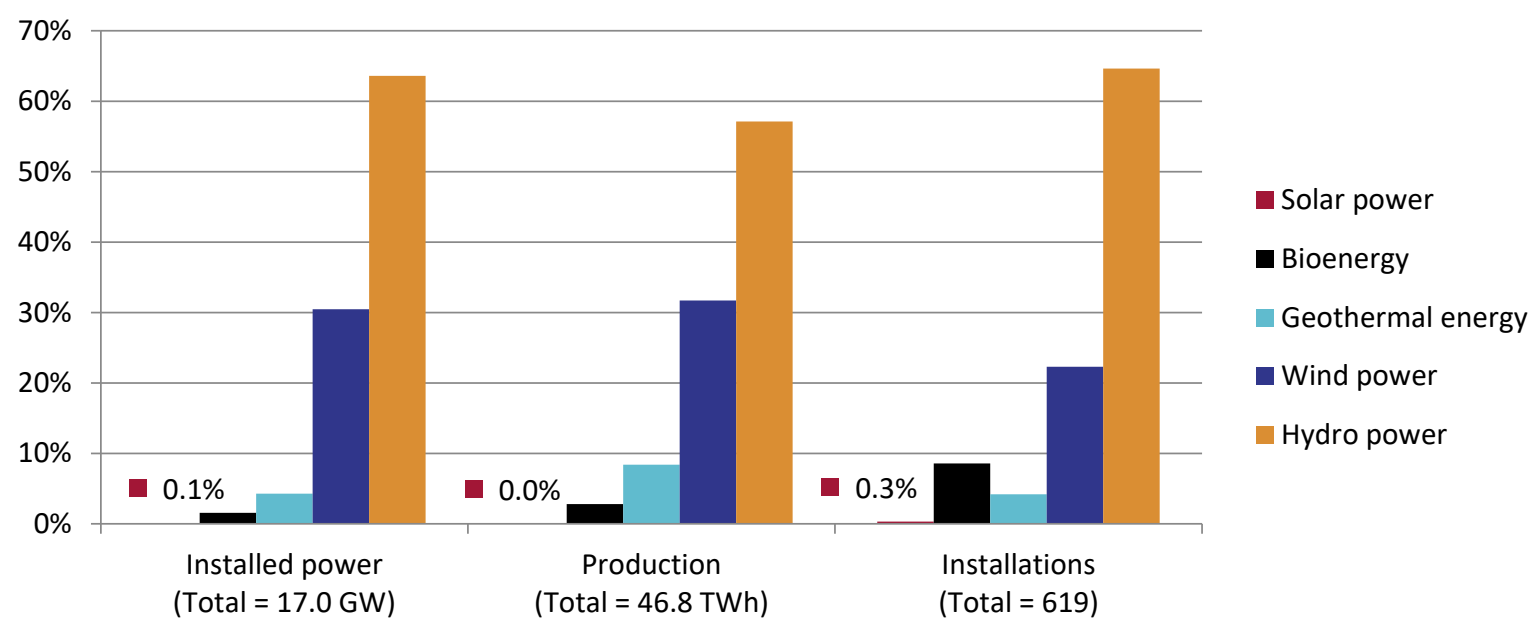

Note: Based on data from the Energy Market Regulatory Authority of Turkey (EPDK, 2019). Only power plants that produced in 2017 are counted.

Wind power producers in Turkey can apply for favourable feed-in tariffs that are regulated under the YEKDEM scheme. If granted a licence, the scheme guarantees a price of 0.073 US dollars per kWh for the first ten years of operation. Producers must apply for feed-in tariffs prior to 2020. A local-content bonus is added to the feed-in tariffs if the plant components are produced in Turkey. The bonus is available for the first five years of operation and ranges from 0.006-0.037 US dollars per kWh for wind power producers ${ }^{10}$.

\footnotetext{
${ }^{7}$ In our sample, only $17 \%$ of the power plants produced more than that ex ante estimate and on average, the ex ante estimate is $41 \%$ larger than the actual production.

${ }^{8}$ The marginal share of solar power is striking. Bhattacharjee et al (2018) found that the licensing process for solar PV plants is lengthy and complex and that installations with less than one MW capacity are not eligible for the local-content bonus. Furthermore, it is argued that feed-in tariff guarantees for ten years are rather short for solar power installations. As the licensing process is complicated and the benefits are not very large, most solar power projects in Turkey are outside the YEKDEM scheme.

${ }^{9}$ For the entire analysis, we excluded power plants in YEKDEM that did not produce electricity in 2017 (three in total). These are plants that underwent maintenance or upgrades, or that were still under construction in 2017.

${ }^{10}$ The exact bonus amount depends on which component is produced domestically. For wind power producers, the bonus is 0.008 US dollars $/ \mathrm{kWh}$ for blades, $0.01 \mathrm{US}$ dollars $/ \mathrm{kWh}$ for generator and power electronics, $0.006 \mathrm{US}$ dollars $/ \mathrm{kWh}$ for turbine towers and 0.013 US dollars/kWh for all mechanical parts (IEA, 2011).
} 
Using information from the Energy Market Regulatory Authority of Turkey (EPDK in Turkish) on the feed-in tariffs and bonus rates received by each wind power plant participating in the YEKDEM scheme in 2017, we know the final feed-in tariff rate per plant in 2017. We assume these rates remain constant throughout the first five years of operation ${ }^{11}$. During the subsequent five years, plants are assumed to receive the feed-in tariff rate without any bonus (i.e. they receive 0.073 US dollars per kWh). Finally, during the remaining lifetime, we assume plants are remunerated with the wholesale market price. We calculated the average wholesale price for $2017^{12}$ and converted it to US dollars ${ }^{13}$. This gives a wholesale price of 44.91 US dollars per MWh, which we leave unchanged throughout the project lifetime ${ }^{14}$.

The costs of wind power plants consist of capital costs and operations and maintenance (0\&M) costs. Capital costs are one-time expenses for the construction of the power plants. Unfortunately, the EPDK database does not provide individual cost information. We approximate capital costs using a dataset from the Turkish Mid-size Sustainable Energy Financing Facility (MidSEFF) ${ }^{15}$. This dataset contains information on 21 wind power projects in Turkey that were partially financed by MidSEFF. We used total project cost and project size (in MW) to calculate the mean project cost per MW for wind installations in Turkey ${ }^{16}$. To account for 0\&M costs, we relied on estimates from IEA \& NEA (2015) who found average 0\&M costs of 21.38 US dollars per MWh for wind power plants in Turkey. This figure is in 2013 US dollars and we therefore converted it to 2017 US dollars. We kept 0\&M costs constant during the lifetime of the investment. This is because a large share of the 0\&M cost is labour compensation and therefore, in contrast to equipment costs, is unlikely to have fallen significantly between 2013 and 2017.

\footnotetext{
${ }^{11}$ Eight plants did not receive a bonus in 2017, but had a positive bonus rate in 2015 and/or 2016 (i.e. their bonuses had expired in 2017). As these bonuses were factored into the investment decisions, investors actually expected a higher FIT rate than we assume. We therefore included these bonus amounts in the analysis as a robustness test (see Table 3). The results remain qualitatively unchanged.

${ }^{12}$ We calculated the average market clearing price for 2017 using data from the Energy Exchange Istanbul (2018).

${ }^{13}$ Using the average 2017 US dollar/lira exchange rate from OECD (2019b).

${ }^{14}$ There are also price reductions in electricity production licenses (Ertürk, 2012). We ignored these for simplicity.

${ }^{15}$ MidSEFF is a project of the European Bank for Reconstruction and Development (EBRD) that provides one billion euros in loans to Turkish private-sector borrowers to finance mid-size investments in renewable energy and energy efficiency in Turkey.

${ }^{16}$ Projects in the MidSEFF dataset range from 2012 and 2018. We converted the data from euros to US dollars using average exchange rates from IMF (2018), and thereafter adjusted for inflation (using data from OECD, 2019b) while assuming that the project costs are denominated in the year in which the plant became operational. Finally, we adjust for changes in capital costs over time, using data on global installed costs of onshore wind power projects from the IRENA Renewable Cost Database (see IRENA, 2018).
} 
The remaining assumptions concern the corporate tax rate, depreciation rule, salvage rate and economic lifetime of wind power projects. In 2017, the corporate tax rate in Turkey was 20\% (OECD, 2018) ${ }^{17}$. For simplicity, we used a linear depreciate rule. Furthermore, in line with IEA \& NEA $(2015)^{18}$, we assumed that $20 \%$ of the initial capital cost could be recovered at the end of the project, either through resale of the installation or through an extension of its running time. In accordance with several studies (listed in Table 1), we used an economic lifetime of 20 years.

Table 1 summarizes the parameters and assumptions required to compute the IRR as described in equation 6 .

Table 1. Baseline parameters and assumptions

\begin{tabular}{|c|c|c|}
\hline & Value & Sources underpinning parameter estimate/assumption \\
\hline \multicolumn{3}{|l|}{ Costs } \\
\hline Capital costs ${ }^{a}$ & $1,346,511$ & MidSEFF (2018), IMF (2018), OECD (2019b), IRENA 2018) \\
\hline $0 \& M \operatorname{costs}^{b}$ & 22.49 & IEA \& NEA (2015), IMF (2018) \\
\hline \multicolumn{3}{|l|}{ Revenue } \\
\hline Market price ${ }^{b}$ & 44.91 & Energy Exchange Istanbul (2018), OECD (2019b] \\
\hline \multicolumn{3}{|c|}{ Further assumptions } \\
\hline Tax rate & $20 \%$ & OECD [2018] \\
\hline Depreciation & Linear & \\
\hline Salvage rate & $20 \%$ & IEA \& NEA [2015] \\
\hline Lifetime & 20 years & Ertürk [2012], Boccard [2010], Waissbein et al [2013] \\
\hline
\end{tabular}
Note: aln 2017 US dollars/MW. ${ }^{b}$ In 2017 US dollars/MWh.

\section{Results}

Our main results rely on production data from 2017. The wind power plants in our dataset produced a combined amount of 14.8 terawatt hours of electricity in 2017. We assumed that this performance is representative and corresponds to investors' production expectations. Therefore, we estimated the IRR by fixing the yearly production amount of each plant at the level of 2017 production.

Table 2 summarizes our calculations and presents the estimated IRR for wind power projects in Turkey. The IRR is estimated at 5.55\%. Figure 2 shows the distribution of IRRs across all 138 wind power installations. The

${ }^{17}$ We assumed that projects with negative profits pay zero tax.

${ }^{18}$ See p. 33 of IEA \& NEA [2015). 
distribution resembles a normal distribution with a slight positive skew and a mean of $4.97 \% .17$ installations (12\%) have an IRR below zero, the median installation has an IRR of $5.48 \%$ and 25 installations [18\%] have an IRR of at least $8 \%$.

Table 2. IRR for the 138 wind power projects in YEKDEM [2017 production scenario]

\begin{tabular}{|c|c|}
\hline $\begin{array}{l}\text { Total production (MWh) } \\
\text { Total capacity (MW) }\end{array}$ & $\begin{array}{r}14,849,007 \\
5,188 \\
\end{array}$ \\
\hline \multicolumn{2}{|c|}{ Revenue [million US dollars] } \\
\hline Annual revenue (years 1-5) & 1,144 \\
\hline Annual revenue (years 6-10) & 1,084 \\
\hline Annual revenue (years $>10$ ) & 667 \\
\hline \multicolumn{2}{|c|}{ Costs [million US dollars] } \\
\hline Capital costs & 6,985 \\
\hline Annual $0 \& M$ costs & 334 \\
\hline \multicolumn{2}{|c|}{ Taxation expense [million US dollars] } \\
\hline Annual taxation expense (years 1-5] & 106 \\
\hline Annual taxation expense (years 6-10) & 94 \\
\hline Annual taxation expense (years $>10$ ) & 14 \\
\hline \multicolumn{2}{|c|}{ Net cash flow [million US dollars] } \\
\hline Annual net cash flow (years 1-5) & 704 \\
\hline Annual net cash flow (years 6-10) & 656 \\
\hline Annual net cash flow (years >10) & 319 \\
\hline IRR & $5.55 \%$ \\
\hline
\end{tabular}

We perform different robustness checks to validate our baseline results. First, there might be various reasons why some projects show negative IRRs. One might be that investors are too optimistic when assessing new projects. Another might be that many installations are not operating at full capacity because they were recently completed. Both cases imply that, ex ante, investors might expect an IRR exceeding the value in Table 2 over the course of the project lifetime. 


\section{Figure 2. Distribution of IRRs for wind power projects in Turkey}

25

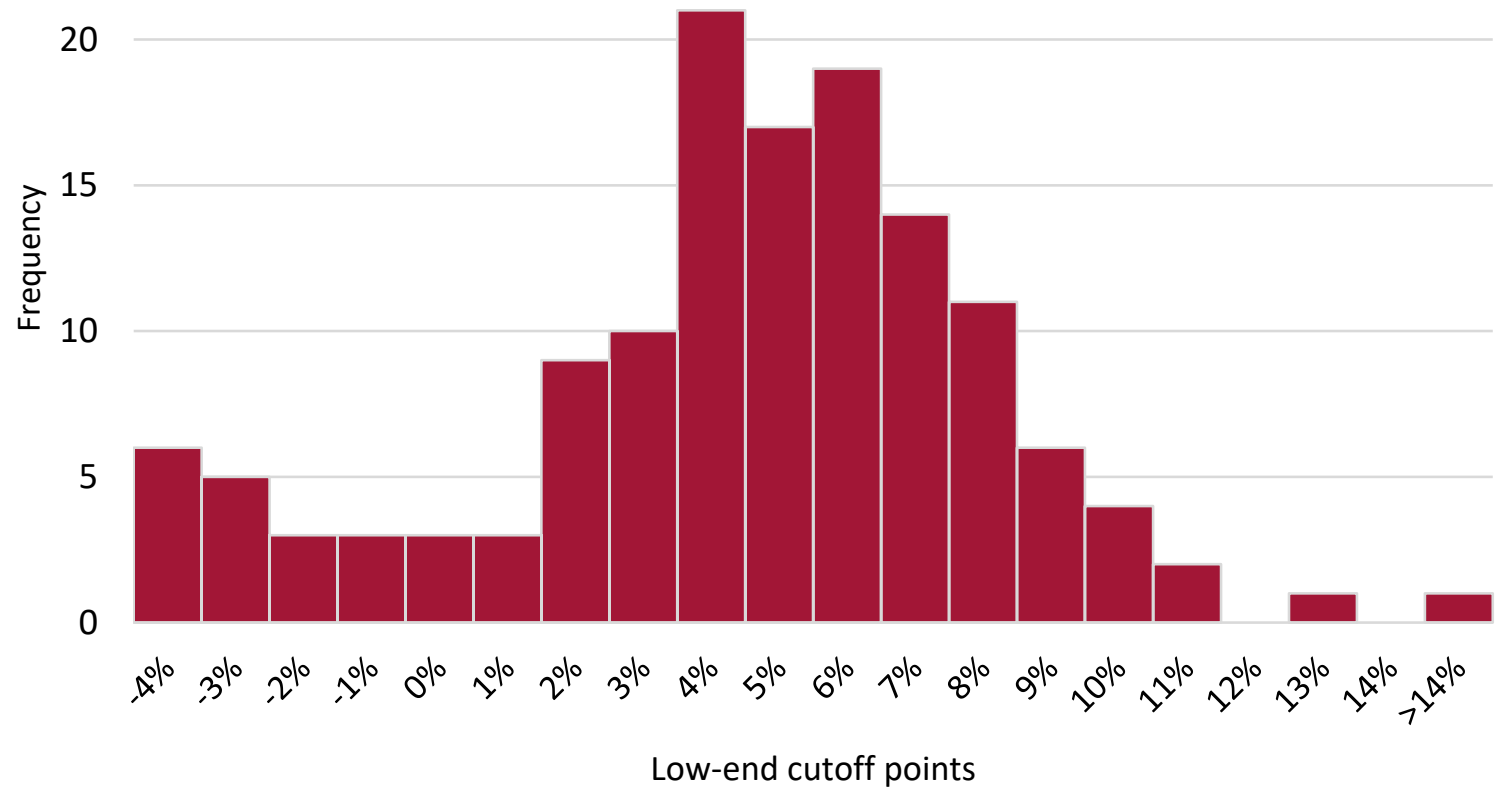

We therefore estimated an 'optimal production scenario' using ex ante production estimates reported in the license of each plant. These estimates are optimistic and correspond on average to a utilization rate of $46 \%$ of the installed capacity ${ }^{19}$. The value of all other parameters remain the same as in the 2017 scenario [specified in Table 1). Under these conditions, the IRR is $10.06 \%$. Since the production levels in the license typically exceed the actual production volumes in 2017, this scenario represents an upper bound on what investors can expect from a wind power project.

Second, we change some of the baseline parameters and assumptions. Table 3 shows that alternative specifications do not change the IRR estimates significantly. The highest estimates occur for a lower tax rate or a higher market price. Overall, the sensitivity analysis suggests an upper IRR bound of around $12 \%$.

\footnotetext{
${ }^{19}$ The corresponding rate for the actual production levels is $33 \%$.
} 
Table 3. Sensitivity analysis

\begin{tabular}{|c|c|c|c|}
\hline $\begin{array}{l}\text { Parameter/assumption } \\
\text { changed }\end{array}$ & New parameter/assumption & $\begin{array}{r}\text { IRR [2017 } \\
\text { production] }\end{array}$ & $\begin{array}{l}\text { IRR [optimal } \\
\text { production] }\end{array}$ \\
\hline Higher capital costs ${ }^{a}$ & $1,507,671^{b}$ & $4.35 \%$ & $8.42 \%$ \\
\hline Lower 0\&M costs ${ }^{c}$ & 20 & $6.21 \%$ & $10.90 \%$ \\
\hline Market price $+25 \%^{c}$ & 56.1 & $6.58 \%$ & $11.04 \%$ \\
\hline Market price - $25 \% \mathrm{c}$ & 33.7 & $4.13 \%$ & $8.80 \%$ \\
\hline Higher tax rate & $30 \%$ & $4.78 \%$ & $8.73 \%$ \\
\hline Lower tax rate & $10 \%$ & $6.32 \%$ & $11.40 \%$ \\
\hline Higher salvage value & $30 \%$ & $5.81 \%$ & $10.14 \%$ \\
\hline Longer economic lifetime & 25 years $^{d}$ & $5.91 \%$ & $10.21 \%$ \\
\hline Past bonus rates added & NA & $5.56 \%$ & $10.08 \%$ \\
\hline
\end{tabular}

Note: aln 2017 US dollars/MW. blEA \& NEA (2015) reported an overnight cost (which encompasses pre-construction,

construction, and contingency costs, but not interest expenses during construction] of 1,667,000 US dollars/MW for installed onshore wind power projects in Turkey. This figure is in 2013 US dollars, and we therefore adjusted it for changes in US inflation (5.19\%) and for changes in global average installed costs of onshore wind power projects (-14\%) between 2013 and 2017. The inflation data were sourced from IMF (2018) and the installed cost data from the IRENA Renewable Cost Database (see IRENA, 2018). In 2017 US dollars/MWh. ${ }^{~}$ See for instance IEA \& NEA (2015) and Simoes et al (2013). ${ }^{\text {TThe }}$ bonus rates of eight power plants in 2015 and/or 2016 were added to the analysis. These plants' bonuses were zero in 2017 suggesting they had expired.

From the preceding calculations we can derive a reasonable range of the cost of capital. As equation 5 implies, the cost of capital for Turkish wind power plants is below the IRR. Our analysis shows that an investor with perfect foresight, investing in an average wind power project in Turkey, should expect a cost of capital of $5.55 \%$ or less. An investor who expects to produce an optimal amount as stipulated in the license will expect a cost of capital of $10.06 \%$ or less.

\section{Calculating the cost of governmental wind power support}

Between 2012 and 2017, the total electricity production registered with YEKDEM increased from 5.2 to 50.5 TWh (EPDK, 2018). Table 4 shows that between 2016 and 2017, compensation in US dollars under YEKDEM rose by $21 \%$ (not correcting for inflation) and compensation in Turkish lira increased by $46 \%$ (not correcting for inflation]. $31 \%$ of the total YEKDEM compensation in 2017 was awarded to wind power installations. It is clear that 
the rapid increase of the total compensation in Turkish lira was largely driven by the strong depreciation of the Turkish lira against the US dollar.

As grid operators are required to pay plant operators the guaranteed feed-in tariffs, the total costs of the YEKDEM scheme are borne by Turkish electricity consumers via their electricity bills. Between 2016 and 2017, the Turkish market clearing price for electricity in Turkish lira increased by 13.4\% (EPDK, 2018). Because of high inflationary pressure in the Turkish economy, this policy of passing on the cost of renewable energy support to endconsumers might draw increasing criticism.

Table 4. Growth in the production by and compensation for all renewable energy projects in the YEKDEM scheme between 2016 and 2017

\begin{tabular}{lr}
\hline Increase in production & $20 \%$ \\
Increase in FIT compensation [US dollars] & $21 \%$ \\
Increase in FIT compensation (Turkish lira) & $46 \%$ \\
\hline Note: Based on data from the Energy Market Regulatory Authority of Turkey (EPDK, 2019) and OECD (2019b). The change in
\end{tabular}

FIT compensation between 2016 and 2017 have intentionally not been corrected for inflation.

Figure 3 compares the production and compensation in 2017 for different technologies. Bioenergy and geothermal installations received a larger share of compensation relative to their share in electricity production. This reflects the higher feed-in tariffs that are granted to these technologies compared to wind power plants. Wind power installations in the YEKDEM scheme produced 14.8 terawatt hours, or $32 \%$ of total production under the YEKDEM scheme in 2017. This production was remunerated with 1.1 billion US dollars, equal to $31 \%$ of total compensation under the YEKDEM scheme. Solar power plants are marginal under the YEKDEM scheme, as the two plants operating in 2017 (both constructed in 2016) produced $2.6 \mathrm{GWh}$ and received around 340,000 US dollars combined.

More than half of the total YEKDEM compensation, almost 2 billion US dollars, was awarded to hydro power plants in 2017. These are plants with a reservoir area of less than 15 square kilometres or situated on rivers, which were constructed after 2005. Hence, the largest hydro power plants in Turkey such as the one installed in the Atatürk dam (2.4 GW capacity), cannot benefit from feed-in tariffs. The largest plant in YEKDEM in 2017 [a hydro power plant) has a capacity of $582 \mathrm{MW}$. 
Figure 3. Share of different technologies in total compensation and production in YEKDEM in 2017

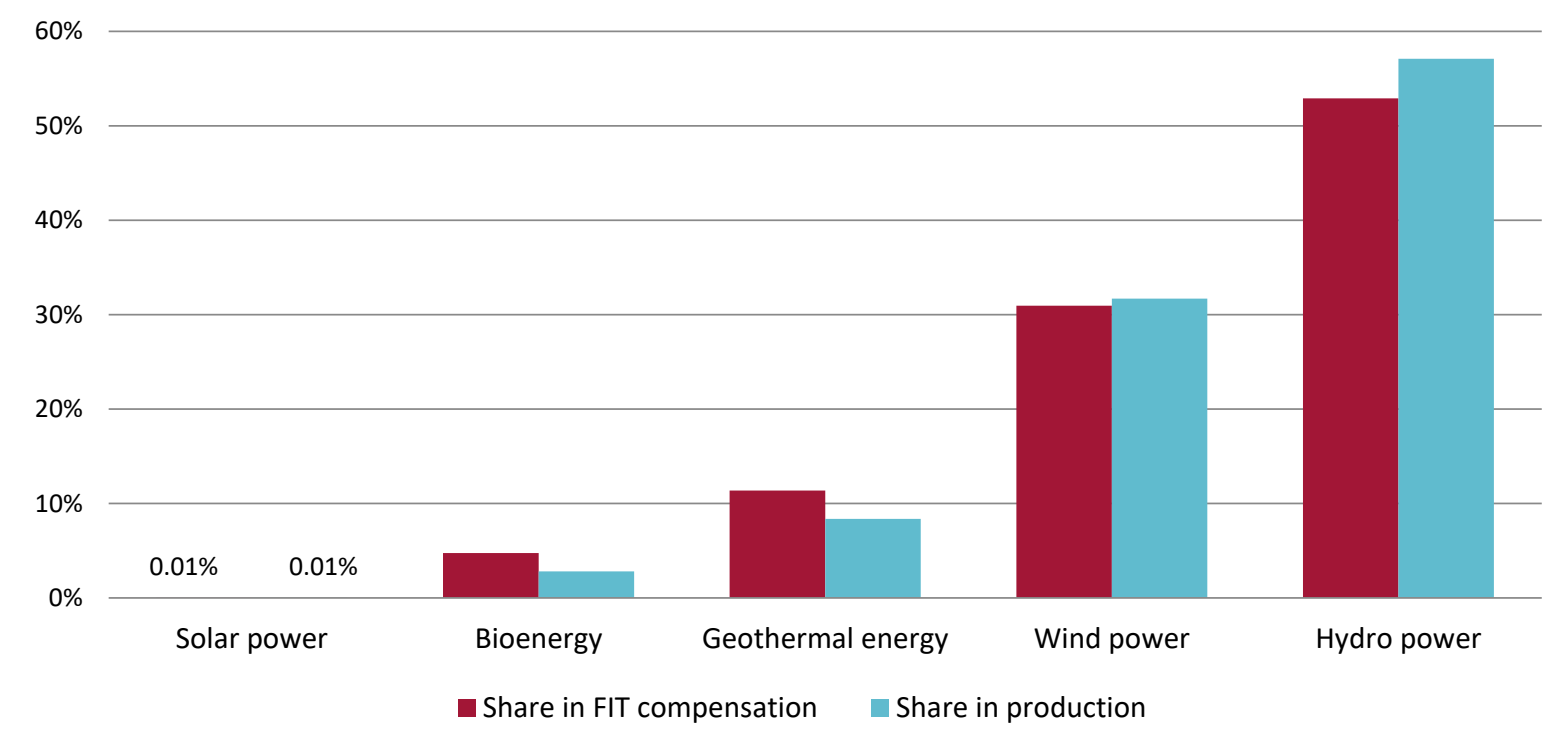

Note: Based on data from the Energy Market Regulatory Authority of Turkey (EPDK, 2019].

\section{Conclusion and policy implications}

We estimated an average internal rate of return of $5.55 \%$ for 138 wind power installations that were registered under the YEKDEM feed-in tariff scheme in 2017. Hence, our analysis suggests the cost of capital for wind power production in Turkey is not higher than the estimates by Tesniere et al (2017) for south-eastern EU member states.

However, an important factor underlying these calculations is the feed-in tariff, which in Turkey is set in US dollars. Because of the severe devaluation of the Turkish lira against the US dollar in recent years, the total cost of the YEKDEM scheme in Turkish lira increased by 46\% between 2016 and 2017. Total YEKDEM compensation for windgenerated electricity stood at 4.2 billion Turkish lira in 2017. Further depreciation of the Turkish lira against the US dollar cannot be ruled out under the prevailing macroeconomic conditions. Therefore, the total cost of the YEKDEM scheme might further increase. Under these circumstances it is plausible that support for the YEKDEM scheme will erode. We argue that the Turkish authorities should maintain their wind power support by guaranteeing the current feed-in tariff rates. 
Many governments have responded to larger than anticipated costs for renewable energy support systems with retrospective changes to feed-in tariffs (EREF, 2013). As a consequence, not only did planned and future renewable energy projects receive lower feed-in tariffs, but also existing projects received lower tariffs than promised. These measures are detrimental to the aim of support schemes. Once feed-in tariff rates are retrospectively changed, the government's commitment to continue these payments is no longer credible and further renewable power projects are unlikely to be realised. Future investors will not only have to calculate on the basis of lower feed-in tariffs but must also discount for the possibility of future rounds of rate reductions. In fact, countries that have enacted retrospective rate changes, such as Spain and Greece, are facing growing gaps between planned capacity and actual installations, as investors have become more cautious (González and Lacal-Arántegui, 2016].

Wind power is a crucial cornerstone of Turkey's future energy supply for three reasons. First, the technical potential of wind power in Turkey is very large. With 114 GW (United Nations Development Programme, 2014), it is larger than the total installed electricity production capacity in Turkey. Second, as no fuel imports are needed for the operation of wind power plants, the establishment of large wind power capacities is an important contribution to reducing Turkey's dependence on foreign energy supplies. Less demand for foreign fossil fuels will help decrease Turkey's current account deficit and strengthen the resilience of the Turkish economy to fossil fuel price volatility. Third, wind power will contribute towards the decarbonization of the Turkish electricity sector and bring other societal benefits. In fact, when accounting for economic, environmental and health costs, wind power is a cheaper source of electricity in Turkey than solar power and coal (IISD, 2015).

It is therefore important that the Turkish authorities continue to show support for the feed-in tariffs that have been granted under the YEKDEM scheme. This will ensure continued investment in small- and medium-sized renewable energy plants, and will also provide credibility to the YEKA programme. If guaranteed feed-in tariffs are reduced retrospectively, investors bidding for YEKA tenders could start discounting promised feed-in tariffs and thus require higher electricity prices to compensate for this uncertainty. Such developments could seriously hamper investment in the wind power sector and renewable energy sector as a whole, impeding Turkey's progress towards its 2023 energy targets. 


\section{Acknowledgements}

The authors are grateful to Bruegel's Michael Baltensperger for the great research assistance provided in the preparation of this paper.

\section{References}

Atilgan, B. and A. Azapagic (2016) 'An integrated life cycle sustainability assessment of electricity generation in Turkey', Energy Policy 93: 168-186

Azman F., H. A. Akyurek, A. T. Akcan, E. Ayhan and U. Erdogan (2015) 'Turkey's New Energy Source: Wind Energy and it's regional capacity', The Journal of Macro Trends in Energy and Sustainability 3 [1]: 46-5?

Bhattacharjee, U., R. K. Goyal, A. Nagpal, S. Chauhan, S. Alam, W. Lise, M. Kocaoglu, G. Tosun, D. KucukbaharBeygo, I. Ozdamar, S. Garud, and A. Datta (2018) Turkey - Rooftop solar market assessment : summary note [English], Washington D.C.: World Bank Group, available at http://documents.worldbank.org/curated/en/532211519629608085/Turkey-Rooftop-solar-marketassessment-summary-note

Boccard, N. (2010) 'Economic properties of wind power: A European assessment', Energy Policy 38 (7): $3232-$ 3244

Bulut, U. and G. Muratoglu (2018) 'Renewable energy in Turkey: Great potential, low but increasing utilization, and an empirical analysis on renewable energy-growth nexus', Energy Policy 123: 240-250

Energy Exchange Istanbul (2018) 'Market Clearing Price', available at https://seffaflik.epias.com.tr/transparency/piyasalar/gop/ptf.xhtml Enerji IQ [2017] 'Turkey To Cut Feed-In Tariffs For Wind And Solar After 2020', available at https://sigmaturkey.com/2017/11/21/turkey-cut-feed-tariffs-wind-solar-2020/ EPDK [2018) Electricity Market Development Report 2017, Republic of Turkey Energy Market Regulatory Authority, available at https://erranet.org/wp-content/uploads/2016/11/Electricity-Market-DevelopmentReport-2017.pdf

EPDK (2019) 'Elektrik Piyasası YEKDEM Listesi', Republic of Turkey Energy Market Regulatory Authority, available at http://www.epdk.org.tr/Detay//cerik/3-0-72/elektrikyekdem 
Ertürk, M. (2012) 'The evaluation of feed-in tariff regulation of Turkey for onshore wind energy based on the economic analysis', Energy Policy 45: 359-36?

European Renewable Energies Federation (EREF) (2013) Policy paper on retrospective changes to RES legislations and national moratoria, available at http://www.keepontrack.eu/contents/publicationsbiannualnationalpolicyupdatesversions/kot-policy-paper-onretrospective-changes-to-res-support.pdf

González, J. S. and R. Lacal-Arántegui (2016) 'A review of regulatory framework for wind energy in European Union countries: Current state and expected developments', Renewable and Sustainable Energy Reviews 56: $588-602$

Hirth, L. and J. C. Steckel (2016) 'The role of capital costs in decarbonizing the electricity sector', Environmental Research Letters 11114010

IEA and NEA (2015) Projected Costs of Generating Electricity 2015 Edition, Paris: OECD Publishing IMF (2018) 'Inflation rate, average consumer prices', IMF Data Mapper, World Economic Outlook [October 2018), available at http://www.imf.org/external/datamapper/PCPIPCH@WEO/OEMDC/

International Energy Agency (IEA) (2011) 'Renewable Energy Law 2010', available at https://www.iea.org/policiesandmeasures/pams/turkey/name-24961-en.php International Institute for Sustainable Development (IISD) (2015) Subsidies to Coal and Renewable Energy in Turkey, Geneva: Global Subsidies Initiative, available at https://www.iisd.org/gsi/sites/default/files/ffsandrens_turkey_coal_eng.pdf Invest in Turkey (2018) Turkey's Renewable Energy Market and Investment Opportunities, available at http://www.invest.gov.tr/en-US/infocenter/publications/Documents/RENEWABLES.ENERGY.INDUSTRY.pdf IRENA (2018) Renewable Power Generation Costs in 2017, International Renewable Energy Agency, Abu Dhabi, available at https://www.irena.org/publications/2018/Jan/Renewable-power-generation-costs-in-2017 MidSEFF (2018) 'MidSEFF projects', available at http://www.midseff.com/portfolio.php Noothout, P., D. de Jager, L. Tesnière, S. van Rooijen, N. Karypidis, R. Brückmann, F. Jirouš, B. Breitschopf, D. Angelopoulos, H. Doukas, I. Konstantinavičiūtè and G. Resch (2016) The impact of risks in renewable energy 
investments and the role of smart policies, DiaCore, available at http://diacore.eu/images/files2/WP3-

Final\%20Report/diacore-2016-impact-of-risk-in-res-investments.pdf

OECD (2018) ‘OECD Tax Database: Table Il.1. Statutory corporate income tax rate', available at

https://stats.oecd.org/index.aspx?DataSetCode=TABLE II1

OECD (2019a] 'FDI flows (indicator'), doi: 10.1787/99f6e393-en, available at https://data.oecd.org/fdi/fdiflows.htm

OECD (2019b) 'PPPs and exchange rates', OECD National Accounts Statistics (database), available at https://doi.org/10.1787/data-00004-en

Pasaoglu, G., N. P. Garcia and G. Zubi (2018) 'A multi-criteria and multi-expert decision aid approach to evaluate the future Turkish power plant portfolio', Energy Policy 119: 654-665

Republic of Turkey Ministry of Energy and Natural Resources [2019a] 'Elektrik', available at http://enerji.gov.tr/tr-TR/Sayfalar/Elektrik

Republic of Turkey Ministry of Energy and Natural Resources [2019b] 'Wind', available at https://www.enerji.gov.tr/en-US/Pages/Wind

Republic of Turkey Ministry of Foreign Affairs (n.d.) 'Turkey's Energy Profile and Strategy', available at http://www.mfa.gov.tr/turkeys-energy-strategy.en.mfa

Sengul, E. (2018) 'Energy incentives prioritized for Turkish economy plan', Anadolu Agency, 20 September 2018, available at https://www.aa.com.tr/en/energy/energy-diplomacy/energy-incentives-prioritized-forturkish-economy-plan/21693

Simoes, S., W. Nijs, P. Ruiz, A. Sgobbi, D. Radu, P. Bolat, C. Thiel and S. Peteves (2013) The JRC-EU-TIMES modelAssessing the long-term role of the SET Plan energy technologies, Report EUR 26292, Luxembourg: Publications Office of the European Union.

Simsek, H. A. and N. Simsek (2013) 'Recent incentives for renewable energy in Turkey', Energy Policy 63: 521 530

Steckel, J. C. and M. Jakob [2018] 'The role of financing cost and de-risking strategies for clean energy investment', International Economics 155: 19-28

Temperton, I. (2016) Reducing the cost of financing renewables in Europe, study on behalf of Agora Energiewende 
Tesniere, L., D. de Jager, P. Noothout, S. Boutsikoudi, R. Brückmann, F. Borek, I. Naydenova, S. Nicola, B. Valach, M. Dukan, L. Jerkic and M. Dabetic (2017) Mapping the cost of capital for wind and solar energy in South Eastern European Member States, Utrecht: ECOFYS Netherlands B.V, available at https://www.ecofys.com/files/files/ecofys-eclareon-2016-wacc-wind-pv-south-east-europe.pdf Turkish Statistical Institute (2018) Dataset: Main Statistics, Foreign Trade by Years, available at http://www.turkstat.gov.tr/PrelstatistikTablo.do?istab_id=621

United Nations Development Program (2014) Renewable energy snapshot: Turkey, available at http://www.sa.undp.org/content/turkey/en/home/library/environment_energy/renewable-energy-snapshot-turkey.html

Waissbein, 0., Y. Glemarec, H. Bayraktar and T. S. Schmidt (2013) Derisking Renewable Energy Investment. A Framework to Support Policymakers in Selecting Public Instruments to Promote Renewable Energy Investment in Developing Countries. New York: United Nations Development Programme 